University of Nebraska - Lincoln

DigitalCommons@University of Nebraska - Lincoln

Faculty Publications from the Harold W. Manter Laboratory of Parasitology

$2-2010$

\title{
A New Species of Trichostrongyloid in African Buffalo (Syncerus caffer) (Artiodactyla: Bovinae) from Uganda
}

\author{
Eric P. Hoberg \\ United States Department of Agriculture, eric.hoberg@ars.usda.gov \\ Arthur Abrams \\ United States Department of Agriculture \\ Patricia A. Pilitt \\ United States Department of Agriculture
}

Follow this and additional works at: https://digitalcommons.unl.edu/parasitologyfacpubs

Part of the Parasitology Commons

Hoberg, Eric P.; Abrams, Arthur; and Pilitt, Patricia A., "A New Species of Trichostrongyloid in African Buffalo (Syncerus caffer) (Artiodactyla: Bovinae) from Uganda" (2010). Faculty Publications from the Harold W. Manter Laboratory of Parasitology. 320.

https://digitalcommons.unl.edu/parasitologyfacpubs/320

This Article is brought to you for free and open access by the Parasitology, Harold W. Manter Laboratory of at DigitalCommons@University of Nebraska - Lincoln. It has been accepted for inclusion in Faculty Publications from the Harold W. Manter Laboratory of Parasitology by an authorized administrator of DigitalCommons@University of Nebraska - Lincoln. 


\title{
A NEW SPECIES OF TRICHOSTRONGYLOID IN AFRICAN BUFFALO (SYNCERUS CAFFER) (ARTIODACTYLA: BOVINAE) FROM UGANDA
}

\author{
Eric P. Hoberg, Arthur Abrams, and Patricia A. Pilitt \\ United States National Parasite Collection and Animal Parasitic Disease Laboratory, United States Department of Agriculture, \\ Agricultural Research Service, BARC East, Bldg. 1180, 10300 Baltimore Avenue, Beltsville, Maryland 20705. e-mail: Eric.Hoberg@ars.usda.gov
}

\begin{abstract}
Africanastrongylus giganticus n. sp. is described based on large ostertagiine nematodes occurring in the abomasum of African buffalo, Syncerus caffer, from Uganda; this represents the second species recognized in the genus. Specimens of $A$. giganticus are characterized by large size (15-19 $\mathrm{mm}$ in total length), a strongly tapering synlophe in the cervical region, and a great number of ridges at all levels of the body (maximum 72 attained in the third quarter); numbers of ridges exceed that reported among any known genera and species of the Ostertagiinae. We refer A. giganticus to this genus based on a strongly tapering lateral synlophe, relatively large numbers of ridges at all levels of the body, miniscule cervical papillae, poorly demarcated divisions of the ovejector, absence of vulval cuticular inflations, and the presence of slightly protruding lips at the vulva. It is distinguished from its congener, Africanastrongylus buceros, in total length, maximum number of ridges (68-72 vs. 53, respectively), structure and disposition of the synlophe, presence of strongly spiraled ovarian tracks, and eggs that are distributed in 3 or more rows in the uterus. A superficial resemblance to Longistrongylus meyeri, the only other large ostertagiine in the African fauna, is evident; these species, however, are distinct based on the synlophe and other characters. Recognition of a second species of Africanastrongylus represented by nematodes of large size suggests that prior reports of L. meyeri in Syncerus caffer may be attributable to A. giganticus.
\end{abstract}

Ostertagiine and other abomasal nematodes associated with African or Cape buffalo (Syncerus caffer (Sparrman)) across the geographic range of this large bovid in sub-Saharan Africa have rarely been reported (Hoberg, Abrams, and Ezenwa, 2008). Among the medium stomach worms, published records are limited to Longistrongylus meyeri Le Roux, 1931 and an unidentified species of Ostertagia Ransom, 1907 from Uganda, and Africanastrongylus buceros Hoberg, Abrams, and Ezenwa, 2008 from Uganda, Kenya, and South Africa (Dinnik et al., 1963; Bwangamoi, 1968; Hoberg, Abrams, and Ezenwa, 2008). Haemonchine nematodes, including species of Haemonchus Cobb, 1898 and Ashworthius Le Roux, 1930 have also been found in African buffalo (Hoberg, Abrams, and Ezenwa, 2008).

Surveys of abomasal nematode diversity among African ungulates were conducted by J. Bindernagle at localities in Uganda during the late 1960s; specimens from these collections were initially evaluated at the U.S. National Parasite Collection by W. W. Becklund and M. L. Walker and later by J. R. Lichtenfels (U.S. National Parasite Collection, unpubl. documents). Comparative morphological studies by W. W. Becklund and M. L. Walker noted the distinctive nature of some of these abomasal nematodes, which were subsequently described and referred to new genera and species among the Ostertagiinae (Hoberg, Abrams, and Ezenwa, 2008; Hoberg, Abrams, and Pilitt, 2009a).

Among the materials of the Bindernagle Collection were specimens of abomasal nematodes found in 8 African buffalo from Uganda. Of these, small male and female ostertagiine nematodes in 2 hosts were included among the type series for Africanastrongylus Hoberg, Abrams, and Ezenwa, 2008. Additional female specimens (4 and 5 adult nematodes) of a substantially larger trichostrongyloid were found in 2 other hosts from separate localities in Uganda, but were not considered in detail during studies that established Africanastrongylus. These 9 specimens, attaining nearly $20 \mathrm{~mm}$ in maximum length, were initially referred to an unidentified species of Bigalkenema Ortlepp, 1963 and later to Longistrongylus meyeri Le Roux,

Received 8 April 2009; revised 16 October 2009; accepted 19 October 2009.

DOI: $10.1645 / G E-2122$
1931, due to their large size (U.S. National Parasite Collection, unpubl. records)

Subsequent evaluations have indicated that these large specimens in S. caffer are distinct from species of Longistrongylus, A. buceros, and other trichostrongyloids known in ungulates from the African fauna. Although the collection localities in Uganda are the same for these large ostertagiines and A. buceros (West Acholi District and Toro District), different host series are involved. We suggest that 2 discrete congeneric ostertagiines are sympatric, occur in $S$. caffer, but have not yet been observed in mixed infections in single hosts.

Initial identification of these large specimens was not accompanied by detailed description of the synlophe or system of surface cuticular ridges characteristic of many trichostrongyloids (Durette-Desset, 1983). The synlophe has been shown to be a definitive character for separating genera and congeneric species among the ostertagiine nematodes even in the absence of male worms (e.g., Lichtenfels, Pilitt, and Lancaster, 1988; Hoberg et al., 1999). Comparative studies of the synlophe, exploring patterns in the cervical region and numbers of ridges at specific levels of the body, were necessary to resolve the identity of the large female nematodes in African buffalo.

Comparisons of the synlophe among species of Longistrongylus Le Roux, 1931, and particularly cotypes and vouchers of $L$. meyeri, has highlighted the distinct nature of these large female specimens in S. caffer (Hoberg, Abrams, and Pilitt, 2009b). Similarity to the synlophe described in A. buceros was apparent, although both the pattern and number of ridges were considered to be sufficiently distinct to warrant recognition of additional species diversity in the genus. We describe and propose a second species of Africanastrongylus in African buffalo, which appears to occur in sympatry with $A$. buceros at a minimum from localities in Uganda.

\section{MATERIALS AND METHODS}

\section{Specimens examined}

Abomasal nematodes in African buffalo or Cape buffalo, Syncerus caffer caffer (Sparrman), were collected at 2 adjacent localities from Uganda by Dr. J. Bindernagle in 1966 and 1967. Specimens included 4 and 5 female nematodes, respectively, in 2 adult buffalo collected near Anaka Village, West Acholi District, and Queen Elizabeth National Park, Toro 
District. These specimens have been archived permanently in the U.S National Parasite Collection (USNPC), U.S. Department of Agriculture, Beltsville, Maryland, and are stored in a solution of $70 \%$ ethanol, $5 \%$ glycerin, and $3 \%$ formalin.

\section{Other specimens examined}

Comparative morphological evaluations were made in reference to type and voucher specimens: (1) allotype and other paratypes of Africanastrongylus buceros (USNPC 66,322.02 and 99,546-99,549) in Syncerus caffer; (2) cotypes for Longistrongylus meyeri in Alcelaphus caama (British Museum of Natural History, BMNH 1998.11.20 312-317); and (3) vouchers for L. meyeri in Eudorcas thomsonii (Royal Veterinary College, RVC (International Institute of Parasitology) 1673). Additional specimens and species of African ostertagiines, including species of Longistrongylus and Robustostrongylus aferensis Hoberg, Abrams, and Pilitt, 2009, which were examined as a basis for comparison, have been listed previously (Hoberg, Abrams, and Ezenwa, 2008; Hoberg, Abrams, and Pilitt, 2009a, 2009 b). Nomenclature for ungulate hosts in the present paper is consistent with that of Wilson and Reeder (2005).

\section{Microscopy}

Nematodes were prepared as temporary whole mounts cleared in phenol-alcohol ( 80 parts melted phenol crystals and 20 parts absolute ethanol) and examined with interference contrast microscopy. The synlophe was examined in whole mounts, with particular attention given to the pattern of ridge systems in the cervical zone and their extent posteriad consistent with prior studies among the ostertagiines (Lichtenfels, Pilitt, and Lancaster 1988; Hoberg et al., 1999; Hoberg, Abrams, and Pilitt, 2009b). Patterns for the synlophe in the cervical region are defined according to Lichtenfels, Pilitt, and Lancaster (1988). Transverse sections were hand cut with a cataract knife and mounted in glycerin jelly for 1 specimen. Sections were used to count the number of ridges at the esophageal-intestinal junction (EIJ), first quarter, and midbody of total body length as determined from the anterior; additional counts of ridges from intact specimens are based on reconstructions. Description of the ovejectors is consistent with that of Lichtenfels et al. (2003).

\section{RESULTS}

Field collections to explore helminth diversity among freeranging ungulates in eastern Africa revealed the occurrence of ostertagiine nematodes in 4 of 8 Cape buffalo. Specimens in 2 hosts from the West Acholi District and Toro District of Uganda were naturally infected with a previously unrecognized species referable to Africanastrongylus.

\section{DESCRIPTION}

\section{Africanastrongylus giganticus $\mathrm{n} . \mathrm{sp}$.$$
\text { Figs. 1-13 }
$$

General description: Trichostrongyloidea, uncoiled, relatively large. Cuticle with well-developed synlophe, lacking gradient, with perpendicular orientation; maximum number of ridges 72 in third quarter. Cervical papillae (CP), miniscule, triangular, thorn-like, situated posterior to subventral gland orifices (SVGO) and excretory pore (EXP) near midlength of esophagus. Cuticular ornamentation at EXP lacking. Esophagus with prominent valve at EIJ.

Synlophe: Synlophe bilaterally symmetrical, with ridges extending from base of cephalic vesicle to near caudal extremity in female. Ridges acutely pointed, with perpendicular orientation and absence of gradient, as viewed in transverse section. Anterior to EIJ, cervical pattern, laterally, Type $1 \mathrm{~b}$, strongly tapering; ventrally, Type A, parallel. Continuous subventral and sublateral ridges present in cervical region. Tapering pattern laterally is complex, with pairs initiating symmetrically in the sublateral fields, and converging and terminating on the lateralmost ridge in posterior region of cervical zone. Overall, 5-6 pairs of ridges terminate along lateralmost ridge in cervical region and tapering pattern extends posterior to the EIJ; termination somewhat asymmetrical, with right and left ridges of respective pairs ending at different levels. Four to five narrowly spaced ridges present in each lateral field. Synlophe initiates, with about 30 ridges at base of cephalic capsule; numbers of ridges increase posteriad from cervical zone, attaining maximum near midbody and into third quarter. At EIJ, ridges number 63-70; in first quarter 63-64; at midbody 66-68; in third quarter 68-72. Synlophe is continuous at vulva and irregular cuticular inflations are absent; ridges terminate ventrally near 300-400 $\mu \mathrm{m}$, laterally about $150 \mu \mathrm{m}$ anterior to anus, and dorsally near level of anus.

Male: currently unknown.

Female: Large nematodes lacking prominent cuticular ornamentation other than synlophe. Total length $(\mathrm{n}=7) 15.6-19.2 \mathrm{~mm}(16.7 \pm 1.21)$ maximum width $(\mathrm{n}=7) 180-210$ attained in region from near midbody to near level of vulva; ratio of total body length:maximum width 1:74-89. Cephalic vesicle 107-112 in length. Esophagus $(\mathrm{n}=7)$ 855-1035 (940 \pm 62) long; 5.1-6.2\% (5.6 \pm 3.5$)$ of total body length. Base of esophagus bulbous, valve at EIJ $(\mathrm{n}=7) 105-125(116 \pm 7.5)$ long, $(\mathrm{n}=7) 78-100(85$ $\pm 10)$ in maximum width. SVGO $(\mathrm{n}=7) 320-442(379 \pm 37)$, nerve ring $(\mathrm{n}$ = 7) 338-425 (393 \pm 28$), \operatorname{EXP}(\mathrm{n}=7) 412-517(482 \pm 34)$, and CP $(\mathrm{n}=7)$ $442-545(511 \pm 33)$ from cephalic extremity; position of EXP at $43-57 \%$ and $\mathrm{CP}$ at $46-61 \%$ of esophageal length from anterior. Ovaries didelphic, amphidelphic, strongly convoluted, spiraled around intestine. Vulva with slightly protruding lips, opens as ventral transverse slit $(n=7)$ at 12.8 $15.7 \mathrm{~mm}$ or $80-83 \%$ ( $81 \pm 1.1)$ of body length from anterior; cuticular inflations and fans absent; synlophe continuous at vulva. Perivulvar pores not seen. Ovejectors well developed, sphincters S1 and S2 not clearly differentiated from vestibule. Total ovejector length $(n=6) 934-1220$ $(1095 \pm 109)$; anterior infundibulum $(\mathrm{n}=6) 212-315(271 \pm 41)$; anterior sphincter, including $\mathrm{S} 1, \mathrm{~S} 2$, and vestibule $(\mathrm{n}=7), 235-310(275 \pm 24)$; posterior sphincter, including S1, S2, and vestibule $(\mathrm{n}=7)$ 235-290 $(262 \pm 25)$; posterior infundibulum $(n=7)$ 207-340 $(271 \pm 41)$. Eggs ovoid, with thin shell $(\mathrm{n}=15), 55-75(69 \pm 8)$ long by 35-45 $(40 \pm 3)$ wide; oriented in multiple rows, usually 3 or more, in anterior and posterior uterine limbs. Tail conical $(n=7) 142-212(182 \pm 25)$, bluntly rounded at caudal extremity, with weak annulations present distal to synlophe termination.

\section{Taxonomic summary}

Host: African buffalo, S. caffer (Sparrman), type host.

Locality: Type locality: In type host from West Acholi District, Uganda; ca. $02^{\circ} 45^{\prime} \mathrm{N}, 032^{\circ} 10^{\prime}$ E. (male host, no. 227 on 31 March 1967).

Other locality: Queen Elizabeth National Park, Toro District, Uganda; ca. $00^{\circ} 19^{\prime} \mathrm{N}, 032^{\circ} 058^{\prime} \mathrm{E}$ (male host, no. 5 on 20 June 1966).

Specimens: Holotype female, USNPC 101,610; male unknown. Paratypes include: (1) USNPC 66,319, from type locality, 3 females; (2) USNPC 92,198, from alternate locality, 3 females and 2 posterior ends.

Etymology: The name "giganticus" refers to the large size of specimens for this species of Africanastrongylus.

\section{Remarks}

In the African fauna, ostertagiines are represented by 10 genera, including 5 that are endemic (Hoberg, Abrams, and Ezenwa, 2008; Hoberg, Abrams, and Pilitt, 2009a). Among this assemblage, Africanastrongylus giganticus n. $\mathrm{sp}$. is immediately excluded from Cervicaprastrongylus Gibbons and Khalil, 1982; Hyostrongylus Hall, 1921; Pseudomarshallagia (Roetti, 1941); Marshallagia (Orloff, 1933); and Hamulonema Hoberg and Abrams, 2008 based on the structure of the strongly tapering Type 1b lateral synlophe (Fig. 1) (Hoberg, Lichtenfels, and Pilitt 1993b; Lichtenfels and Hoberg, 1993; Hoberg and Abrams, 2008; Hoberg, Abrams, and Pilitt, 2009b). Laterally, the cervical synlophe in species referred to these genera is Type 2 parallel. Specimens of A. giganticus are also distinct from Robustostrongylus Hoberg, Abrams, and Pilitt, 2009 based on the structure of esophagus and synlophe, and general proportions of the body (Hoberg, Abrams, and Pilitt, 2009a) (Figs. 18). Differentiation of A. giganticus from Ostertagia Ransom, 1907 and Teladorsagia Andreeva and Satubaldin, 1954 is based on structure of the synlophe, miniscule $\mathrm{CP}$, relative position of the EXP and $\mathrm{CP}$, and absence of flaps and inflations at level of vulva (Lichtenfels and Hoberg, 1993; Hoberg et al., 1999). In further contrast, females of A. giganticus are substantially larger than nematodes referred to any species among this group of 8 genera.

Specimens of $A$. giganticus show resemblance to some species of Longistrongylus. All species of Longistrongylus, however, are generally 


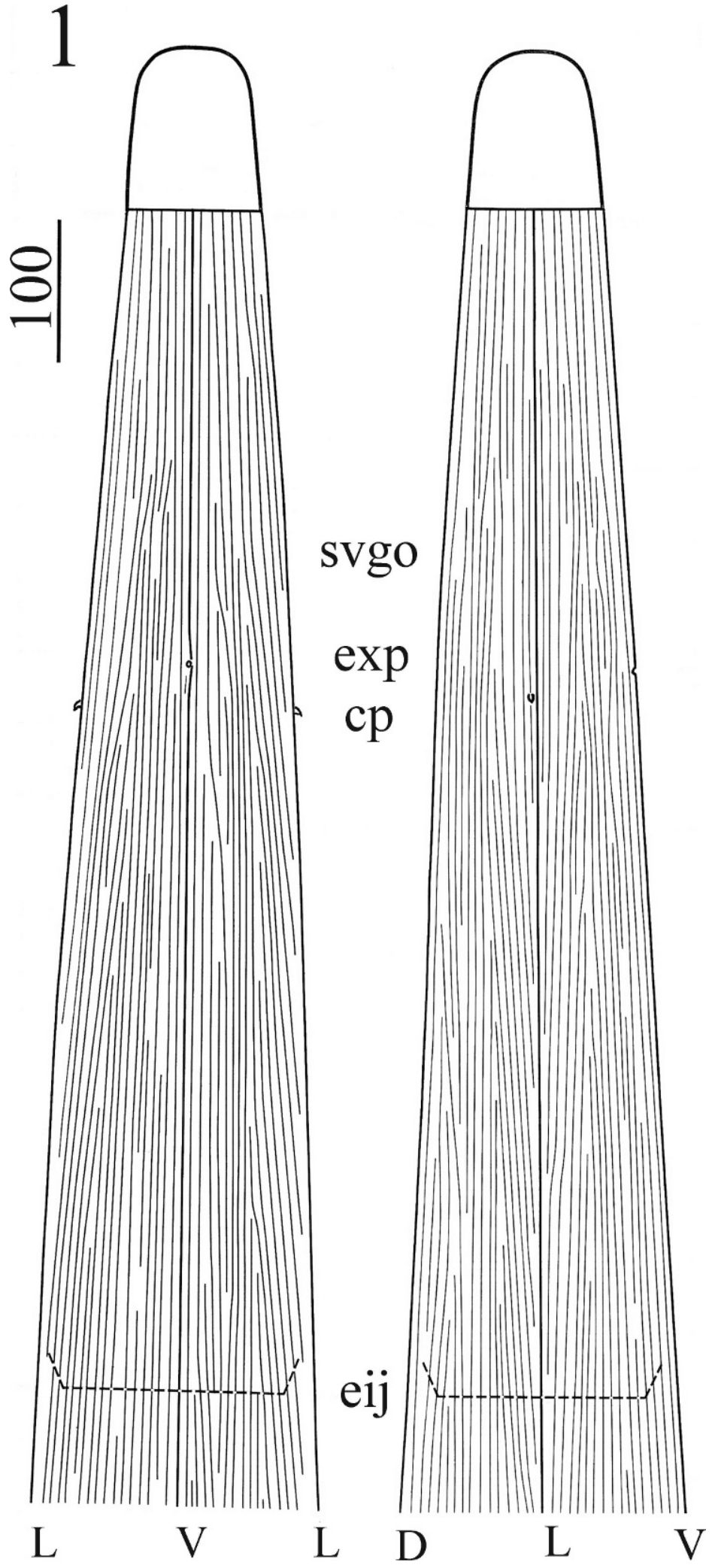

Figure 1. Africanastrongylus giganticus $\mathrm{n}$. sp. showing pattern for the synlophe in ventral and lateral fields in the cervical zone anterior to the base of the esophagus in the holotype specimen. Note strongly tapering Type $1 \mathrm{~b}$ system laterally and parallel Type A ventral system ventrally, and large number of ridges at level of the esophageal-intestinal junction (EIJ). Cervical papillae (CP) adjacent to lateralmost ridge and excretory pore (EXP) on ventralmost ridge; orifices of the subventral esophageal glands (SVGO) are situated anterior to the EXP and CP; orientation is indicated by $\mathrm{L}=$ lateral, $\mathrm{D}=$ dorsal, and $\mathrm{V}$ $=$ ventral

characterized by large $\mathrm{CP}$, relatively few ridges comprising the synlophe (in females usually not exceeding 45 at the midbody), and irregular inflations at the level of the vulva (Gibbons, 1977; Hoberg, Lichtenfels, and Pilitt, 1993a; Hoberg, Abrams, and Pilitt, 2009b). Specimens of $L$. meyeri are an exception among the 8 species of Longistrongylus in having a greater number of midbody ridges (50-58) than congeners and in the absence of cuticular inflations at the vulva.

Specimens of $A$. giganticus are similar to those of $L$. meyeri in large size and overall dimensions, in positions of the EXP and CP relative to mid-length of the esophagus, in spiraled ovarian tracks, structure of the 
Figures 2-3. Synlophe in Africanastrongylus giganticus $\mathrm{n}$. $\mathrm{sp}$. as seen in transverse section in first quarter and at midbody as determined from anterior. Sections are oriented with dorsal to top and ventral to bottom as viewed from the posterior. (2) Paratype female, USNPC 92,198, showing 64 ridges at termination of first quarter. (3) Paratype female, USNPC 92,198 , showing 67 ridges at midbody.

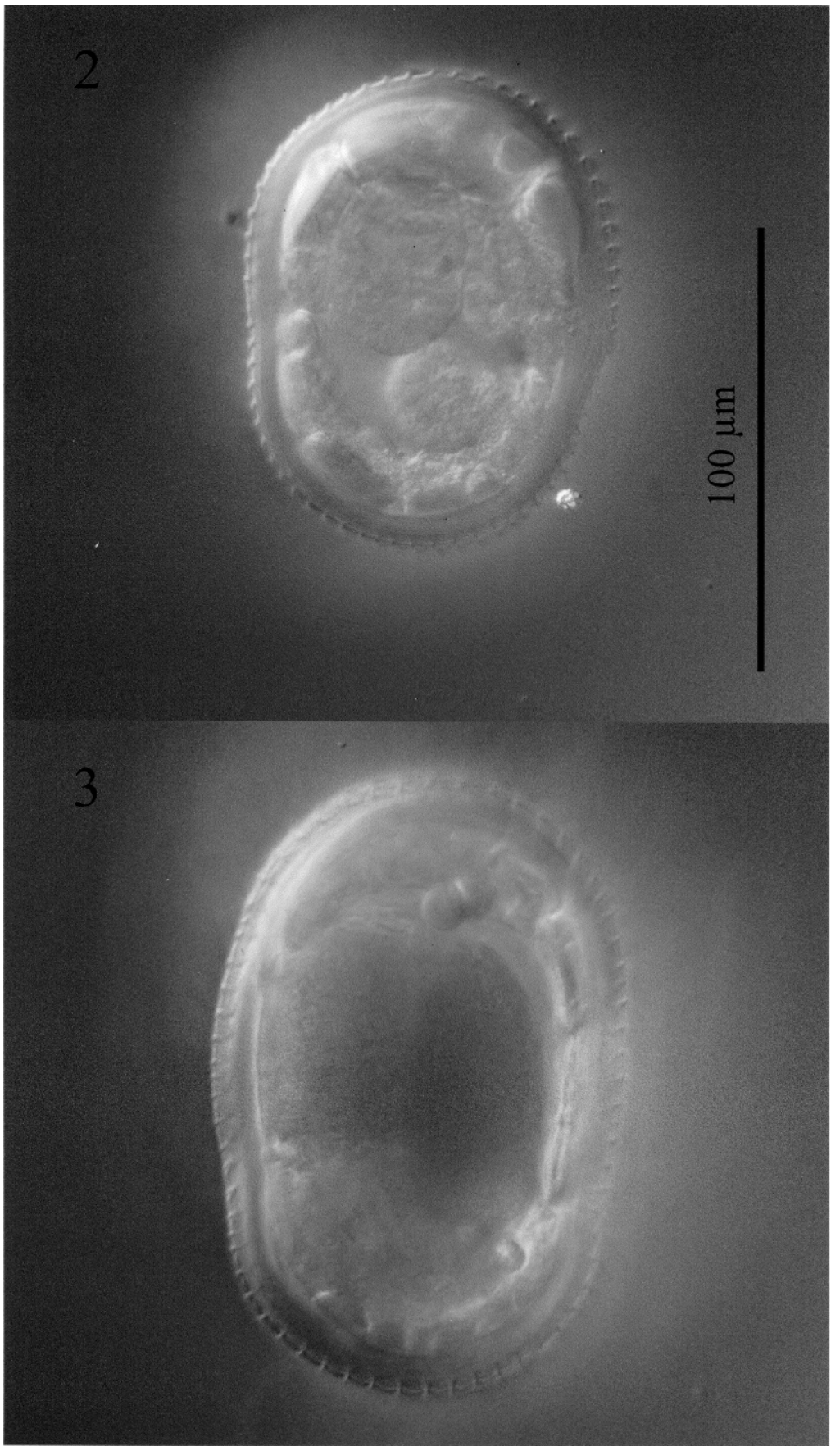

slightly protruding transverse vulva lacking inflations, and in the bluntly rounded and relatively short conical tail (Figs. 4-8, 12). The cotypes for L. meyeri exceed $20 \mathrm{~mm}$ in maximum length and are substantially larger than any other known ostertagiines in the African fauna (Le Roux, 1931; Gibbons, 1977; Hoberg, Abrams, and Ezenwa, 2008; E. P. Hoberg, P. A. Pilitt, and A. Abrams, unpubl. obs.). In L. meyeri, the spiraling for the ovarian tracks can be somewhat variable as indicated by the structure in the cotype specimens (strongly spiraled) and vouchers attributed to this species in Nanger granti (weakly spiraled) (Le Roux, 1931; Hoberg, Abrams, and Pilitt, 2009a). Similarities outlined above are considered to be superficial, as specimens of $A$. giganticus further differ in the strongly tapering lateral cervical synlophe composed of a large number of ridges, and an esophageal-intestinal valve of relatively small dimensions (Figs. 1-4); in females and males of L. meyeri, the lateral synlophe is entirely parallel and the EIV is massive, 150-161 $\mu \mathrm{m}$ in length (E. P. Hoberg, P. A. Pilitt, and A. Abrams, unpubl. obs.).

Although we conclude that $A$. giganticus is not consistent with Longistrongylus, a male counterpart for the former remains to be identified. If attributable to Longistrongylus, this male would have a $2-$ 1-2 bursal form, lack a gubernaculum and proconus, and be otherwise consistent with congeners (Gibbons, 1977; Hoberg, Abrams, and Ezenwa, 2008; Hoberg, Abrams, and Pilitt, 2009a). The male should also agree with respect to the structure of the synlophe (tapering cervical pattern and potentially greater number of ridges than the female) and in the length of the esophageal valve (Hoberg, Abrams, and Pilitt, 2009b). Currently, all male ostertagiines known in the African fauna have been described in association with female conspecifics.

Specimens of A. giganticus have greatest similarity to A. buceros, currently known only in $S$. caffer from Uganda, Kenya, and South Africa 


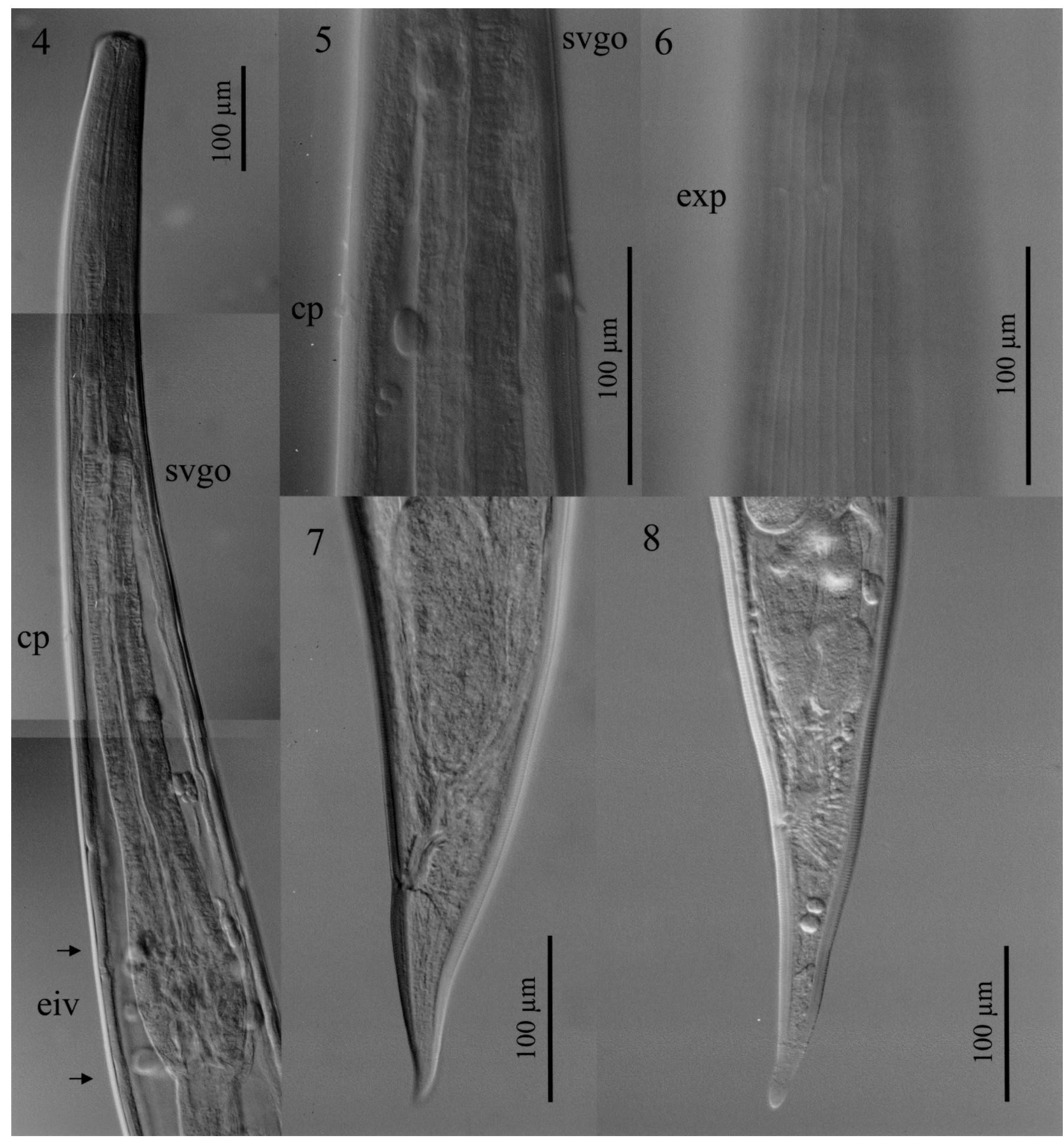

FIGURES 4-8. Cephalic and caudal structure in females of Africanastrongylus giganticus $\mathrm{n}$. sp. as seen in specimens mounted entire and viewed in differential interference contrast. (4) Holotype female, USNPC 101,610, showing ventral view (composite) of cervical region and esophagus. Note positions of the orifices of the subventral glands (svgo), cervical papillae (cp), and structure of the esophageal-intestinal valve (eiv). (5) Holotype female, ventral view in cervical zone, showing structure of miniscule cervical papillae (cp) projecting from the left and right lateral cuticle. (6) Holotype female, ventral view in cervical region showing position of the excretory pore (exp) and structure of parallel Type A ventral synlophe. (7) Paratype female, USNPC 92,198, showing structure of conical tail in left lateral view. (8) Paratype female, USNPC 92,198, showing variation in the structure of the tail.

(Hoberg, Abrams, and Ezenwa, 2008). We refer A. giganticus to this genus based on a strongly tapering lateral synlophe, relatively large numbers of ridges at all levels of the body, miniscule CP, position of the CP and EXP near or slightly posterior to the midlength of the esophagus, poorly demarcated divisions of the ovejector (sphincters S1, S2, and vestibule), absence of vulval cuticular inflations, and presence of slightly protruding lips at the vulva (Figs. 1-5, 9-12). Female specimens of A. giganticus differ substantially from $A$. buceros in total length, maximum number of ridges 


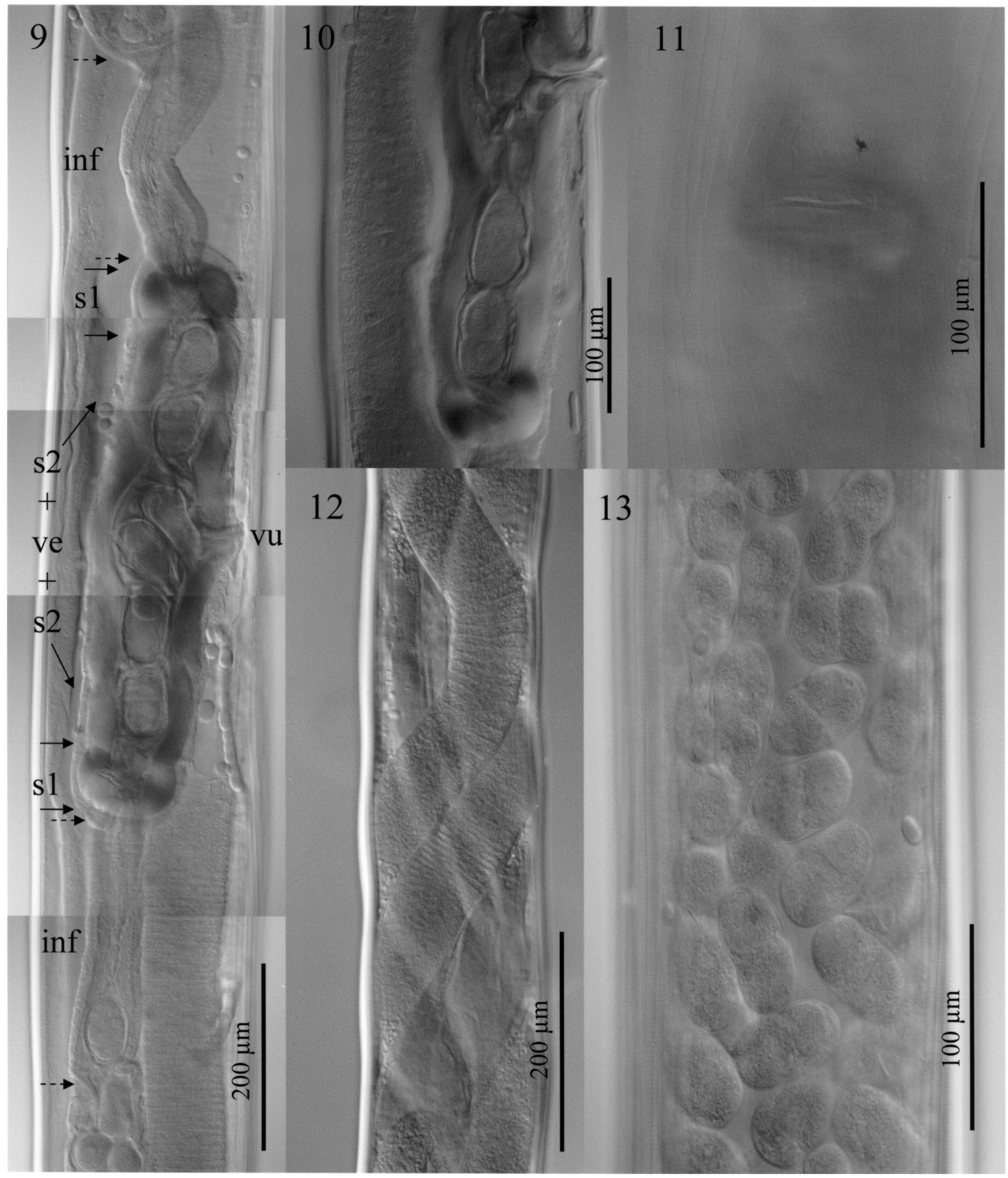

FIGURES 9-13. Ovejectors and associated structural characters of the female genital system in Africanastrongylus giganticus n. sp. (9) Ovjectors in right lateral view of holotype, USNPC 101,610, showing relationships for the vulva (vu), anterior and posterior infundibula (inf), sphincters 1 (s1), and combined sphincters 2 and vestibule (s $2+\mathrm{ve}$ ). Note that the demarcation between $\mathrm{s} 2$ and the vestibule is indistinct. (10) Posterior sphincter, vestibule, and vulva in right lateral view of paratype specimen, USNPC 92,198, showing protruding lip of vulva. (11) Vulva, in ventral view, showing structure and adjacent ridges of the synlophe in paratype specimen, USNPC 92,198. (12) Structure of ovarian limbs, showing spiraled position around the intestine in a paratype USNPC 66,319. (13) Eggs within the uterus of the holotype female, showing disposition in multiple rows and thin-walled structure. 
TABLE I. Comparison of female specimens of Africanastrongylus giganticus n. sp. and Africanastrongylus buceros Hoberg, Abrams, and Ezenwa, 2008.

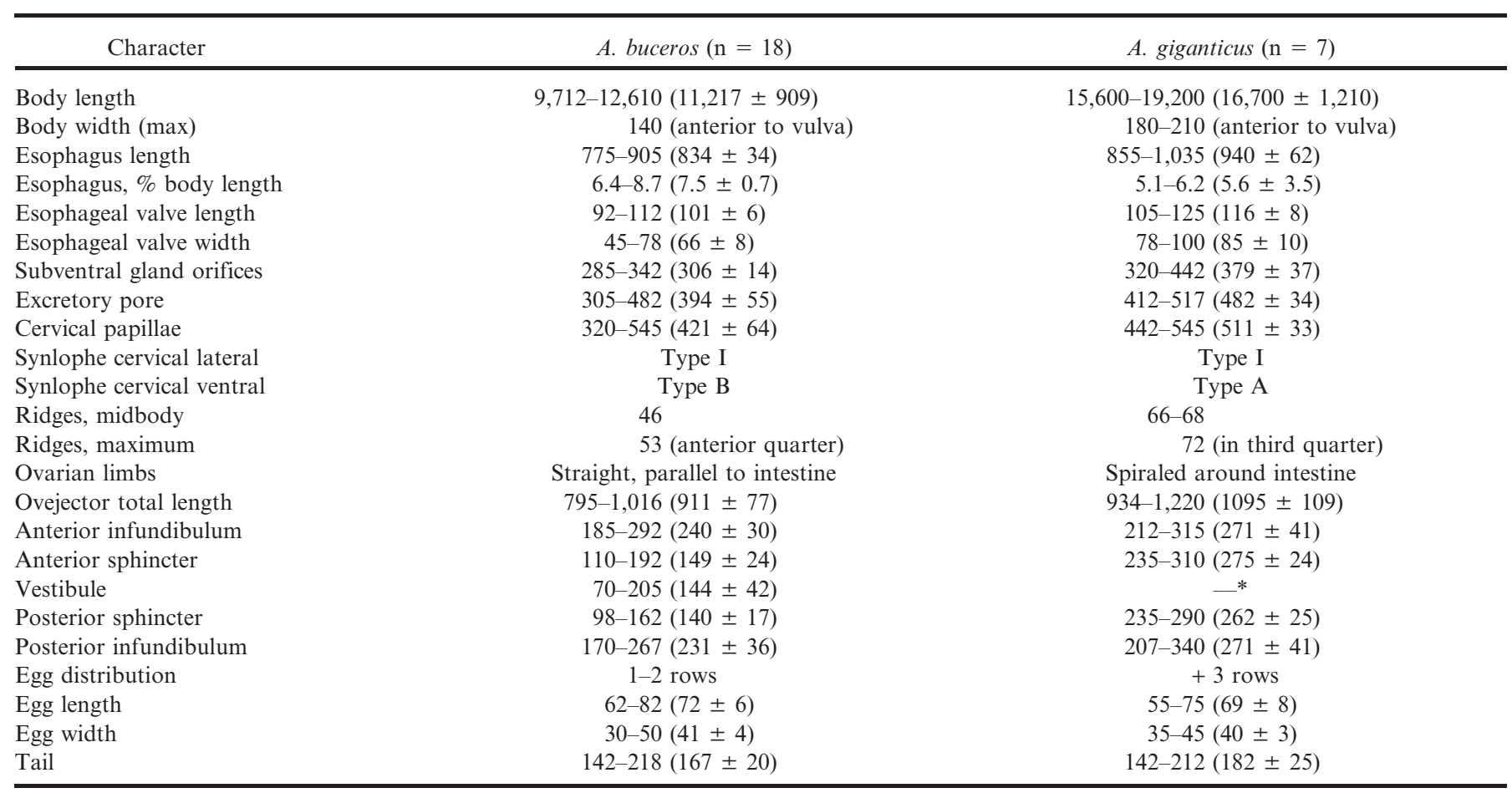

* Vestibule in specimens of A. giganticus is not clearly demarcated from proximal region of S2; measurements for either the anterior or posterior sphincter include S1, S2, and the vestibule.

(68-72 vs. 53), maximum number of ridges comprising the synlophe at any specific level of the body, position where maximum number of ridges is attained posterior to midbody (anterior quarter in A. buceros), and more anterior termination of the synlophe (62-212 laterally and 102-220 dorsoventrally in $A$. buceros) (Table I). Strongly spiraled ovarian tracks are seen only in A. giganticus (parallel to intestine in A. buceros). Eggs are distributed in 3 or more rows in the uterus of $A$. giganticus (Fig. 13), but only in 1-2 rows in specimens of A. buceros.

Presuming that $A$. giganticus is correctly attributed to Africanastrongylus, the male would have a $2-2-1$ bursa, small proconus, thin and filamentous spicules, and a well-developed gubernaculum, and agree in the structure of the strongly tapering Type-1b lateral synlophe and in the length of the esophageal valve. Additionally, it would be predicted, consistent with $A$. buceros, that the male would have a greater number of ridges than the female (Hoberg, Abrams, and Ezenwa, 2008).

We discount the possibility that $A$. giganticus and $A$. buceros represent polymorphic females of a single species. Across the diversity of ostertagiines, polymorphism is known only among male conspecifics (e.g., Dróżdż, 1995). In genera where polymorphism is known, the synlophe does not vary (pattern and ridge number) beyond a definable range among multiple male morphotypes or single females representing a discrete species (e.g., Hoberg et al., 1999). Indeed, this observed degree of uniformity among conspecifics has been the basis of and rationale in applying data for the synlophe when discriminating among species and for identifying polymorphic males and associated females (Lichtenfels, Pilitt, and Lancaster, 1988; Lichtenfels and Hoberg, 1993; Hoberg et al., 1999; Hoberg, Abrams, and Pilitt, 2009b).

\section{DISCUSSION}

\section{Ostertagiines in Syncerus caffer}

Recognition of $A$. giganticus n. sp., represented by nematodes of large size, suggests that prior reports of L. meyeri in Syncerus may be attributable to this species. We have noted a superficial resemblance between A. giganticus and L. meyeri, particularly, large dimensions as indicated by cotype specimens of the latter species (see Le Roux, 1931; Gibbons, 1977; Hoberg, Abrams, and Ezenwa, 2008). Specimens attributed to L. meyeri from this bovid, however, were not included in the redescription by Gibbons (1977), and only material in antelopes was represented.

Longistrongylus meyeri has been the only species of this genus reported in free-ranging Bovinae from Africa (Hoberg, Abrams, and Ezenwa, 2008). The type host for L. meyeri is among the Alcelaphinae, and most records for this ostertagiine are from species among the Antilopinae, Reduncinae, and Hippotraginae (Le Roux, 1931; Gibbons, 1977; Hoberg, Abrams, and Ezenwa, 2008). Specimens reported in African buffalo from Uganda by Dinnik et al. (1963) were not accompanied by redescriptions, nor was it indicated whether vouchers had been deposited in a museum collection; prevalence or intensity of infections among the 10 animals examined was not reported. Bwangamoi (1968) repeats this record and 1 for an unidentified species of Ostertagia, but apparently did not collect additional specimens from $S$. caffer. At the time of these reports, characterization or identification of these worms would not have been based either on the synlophe or structure of the esophageal valve (e.g., Lichtenfels and Hoberg, 1993). Gibbons (1977) did not include material collected by Dinnik et al. (1963) in a redescription of L. meyeri, and our attempts to locate this material in any of the major international collections were unsuccessful. We would conclude that perhaps these records for L. meyeri in $S$. caffer are in error. This would also suggest that species of Longistrongylus may be limited in distribution to antelopes and that typical hosts may not include free-ranging Bovinae (see Hoberg, Abrams, and Ezenwa, 
2008). Further, it is apparent that there is a paucity of voucher specimens that have been deposited in museum collections as a basis for documenting the diversity and structure of the nematode fauna among African ungulates (Hoberg, Abrams and Pilitt, 2009b).

\section{Synlophe as a diagnostic character}

In all specimens of $L$. meyeri examined by us (the only ostertagiine of comparable size in the African fauna), we demonstrated that there is limited and definable variation in the number of ridges comprising the synlophe, respectively, in males and females (Hoberg, Abrams and Pilitt, 2009b). In $L$. meyeri, both very large worms, e.g., cotypes described by Le Roux (1931), and considerably smaller worms, e.g., those in $E$. thomsonii included in the redescription by Gibbons (1977), have comparable numbers of ridges. Thus, the size (diameter) of the worm, either for females or males, does not influence the number of ridges or the pattern, although ridge number varies in a definable manner and sexual dimorphism in this character is evident, particularly in species of Longistrongylus and in $A$. buceros (Boomker and Durette-Desset, 1997; Hoberg, Abrams, and Pilitt, 2009b). These generalities have been demonstrated in Teladorsagia (Hoberg et al., 1999) and established in studies on related ostertagiines (Hoberg, Lichtenfels, and Pilitt, 1993c; Lichtenfels et al., 1993), where ridge number is independent of worm diameter.

Observations imply that irrespective of body size, the number of ridges should not vary beyond a definable range, seldom exceeding 10 at any comparable level of the body for male or female conspecifics (Hoberg, Abrams, and Pilitt, $2009 b$ ). Thus, extreme differences in ridge number, as shown for A. buceros and A. giganticus, would be expected to be diagnostic for species-level diversity. This is similar to the situation for numbers of ridges as observed in Teladorsagia circumcincta (Stadelman, 1894) versus Teladorsagia boreoarcticus Hoberg, Monsen, Kutz, and Blouin, 1999, which have been demonstrated, based on both morphological and molecular criteria, to be poorly differentiated cryptic species.

\section{ACKNOWLEDGMENTS}

We gratefully acknowledge Lynda Gibbons and Mark T. Fox at the Royal Veterinary College, London, and Eileen Harris at the Natural History Museum, London, for their assistance in providing type and voucher specimens for various species of Longistrongylus and, particularly, their attempts to locate specimens from $S$. caffer.

\section{LITERATURE CITED}

Boomker, J., and M.-C. Durette-Desset. 1997. Supplement to the description of Longistrongylus thalae (Troncy and Graber, 1973) Gibbons, 1981 (Nematoda: Ostertagiinae). Systematic Parasitology 36: $69-73$

BwANGAMOI, O. 1968. Helminth parasites of wild and domestic animals in Uganda. Bulletin of Epizootic Diseases of Africa 16: 429-454.

Dinnik, J. A., J. B. Walker, S. F. Barnett, And D. W. Brocklesby. 1963. Some parasites obtained from game animals in western Uganda. Bulletin of Epizootic Diseases of Africa 11: 37-44.
DrózDz, J. 1995. Polymorphism in the Ostertagiinae Lopez-Neyra, 1947 and comments on the systematics of these nematodes. Systematic Parasitology 32: 91-99.

Durette-Desset, M.-C. 1983. Keys to the genera of the superfamily Trichostrongyloidea, Vol. 10. In CIH keys to the nematode parasites of vertebrates, R. C. Anderson and A. G. Chabaud (eds.). Commonwealth Agricultural Bureaux, Farnham Royal, U.K., 86 p.

GibBons, L. M. 1977. Revision of the genera Longistrongylus Le Roux 1931. Kobusinema Ortlepp, 1963 and Bigalkenema Ortlepp, 1963 (Nematoda: Trichostrongylidae). Journal of Helminthology 51: 41-62.

Hoberg, E. P., And A. Abrams. 2008. Hamulonema gen. nov. for Teladorsagia hamata and Ostertagia kenyensis in the ostertagiine fauna (Nematoda: Trichostrongyloidea) from African ungulates. Journal of Parasitology 94: 866-879.

- - AND V. O. Ezenwa. 2008. An exploration of diversity among the Ostertagiinae (Nematoda: Trichostrongyloidea) in ungulates from Sub-Saharan Africa with a proposal for a new genus. Journal of Parasitology 94: 230-251.

, AND P. A. PilitT. 2009a. Robustostrongylus aferensis gen. nov. et sp. nov. (Nematoda: Trichostrongyloidea) in kob (Kobus kob) and hartebeest (Alcelaphus buselaphus jacksoni) from sub-Saharan Africa, with further ruminations on the Ostertagiinae. Journal of Parasitology 95: 702-717.

— - AND $\longrightarrow$ 2009b. Synlophe structure for species of Longistrongylus (Nematoda: Trichostrongyloidea), abomasal parasites among ungulates from sub-Saharan Africa, with comparisons to the global ostertagiine fauna. Journal of Parasitology 95: 1468-1478. , J. R. Lichtenfels, And P. A. Pilitt. 1993a. Synlophe of Cooperia neitzi (Trichostrongylidae: Cooperiinae) with comments on vulval inflations and hypertrophy of cuticular ridges among the trichostrongyloids. Journal of the Helminthological Society of Washington 60: $153-161$

AND 1993b. Affiliation of Hyostrongylus rubidus (Nematoda: Trichostrongylidae) with the Ostertagiinae, and evaluation of the synlophe and other structural characters. Journal of Parasitology 60: 219-233.

- $\longrightarrow$ AND 1 1993c. Comparative morphology of Ostertagia mossi and Ostertagia dikmansi (Trichostrongylidae) from Odocoileus virginianus and comments on other Ostertagia spp. from the cervidae. Systematic Parasitology 24: 111-127.

, K. J. Monsen, S. Kutz, and M. S. Blouin. 1999. Structure, biodiversity, and historical biogeography of nematode faunas in Holarctic ruminants: Morphological and molecular diagnoses for Teladorsagia boreoarcticus n. sp. (Nematoda: Ostertagiinae) a dimorphic cryptic species in muskoxen. Journal of Parasitology 85: 910-934.

Le Roux, P. L. 1931. On Longistrongylus meyeri gen. and sp. nov., a trichostrongyle parasitizing the Red Hartebeest Bubalis caama. Journal of Helminthology 9: 141-146.

Lichtenfels, J. R., And E. P. Hoberg. 1993. The systematics of nematodes that cause ostertagiasis in domestic and wild ruminants in North America: An update and a key to species. Veterinary Parasitology 46: $33-53$ cuticular ridge patterns, and other morphological characters of Mazamastrongylus odocoilei and Mazamastrongylus pursglovei (Nematoda: Trichostrongyloidea) from white-tailed deer Odocoileus virginianus. Systematic Parasitology 24: 1-15.

, P. A. Pilitt, And L. M. GibBons. 2003. Ovejector structure in the Haemonchinae (Nematoda: Trichostrongyloidea) of ruminants. Journal of Parasitology 89: 984-993.

- $\longrightarrow$ AND M. B. LANCASTER. 1988. Cuticular ridge patterns of seven species of Ostertagiinae (Nematoda) parasitic in domestic ruminants. Proceedings of the Helminthological Society of Washington 55: 77-86.

Wilson, D. E., ANd D. M. Reeder. 2005. Mammals species of the world. A taxonomic and geographic reference. Vol. 1. Johns Hopkins University Press, Baltimore, 743 p. 